\title{
The role of waste management in the control of hazardous substances: lessons learned
}

\author{
Henning Friege
}

\begin{abstract}
Background: Sorting and disposal of waste are the last steps in the "lifetime" of a product. If products are contaminated with chemicals assessed to be hazardous for man or environment, waste management has the role of a vacuum cleaner in substance chain management working in two different ways: The hazardous compounds have to be properly separated from potential secondary resources in sorting processes. If this is not possible, those products have to be disposed safely. Starting from the experiences collected with some chemicals banned, the tools used for phasing out these chemicals from the technosphere are studied with respect to their influence on the contamination of the environment.

Results: Even if a dangerous substance has been banned, it is further used in a number of products. In the cases presented here, the substances were banned for further use. In the case of CFCs, the substitutes used have partially also been substituted because of adverse effects. Besides the prohibition of use of hazardous substances, numerous other regulations were issued to reduce unsafe handling and minimize emissions into the environment. It turned out that waste management cannot correct mistakes which already happened "upstream" in the product chain. The control of point sources works quite successfully, whereas today the overwhelming emissions stem from diffuse sources, partially caused by unsafe waste management procedures.

Conclusions: Though there are no complete balances for both groups of compounds serving as examples, some conclusions can be drawn based on the experiences collected. Hazardous compounds may be separated successfully from used products or waste,

- If they are mostly used in industry and not in households,

- if they can be identified as part of certain products,

- if their concentration in these products is rather high,

- if technical problems come up when they contaminate secondary raw materials,

- if there is international support for proper waste management.
\end{abstract}

Keywords: Chemical policy, Waste management, Substance chain management, PCBs, CFCs, H-CFCs, Dissipative use, Globalization, Contamination of secondary resources

\section{Background}

Globalization of consumer products also means global application of chemicals used in these products and also global spread of these chemicals with waste, when the products come to their "end of life". This is not a new experience. In the development of chemical industry, product lines like coal tar dyes were highly significant world wide just a hundred years ago (see for example [1]). In contrary to natural dyes, tar dyes could be standardized.

* Correspondence: hfriege@awista.de

AWISTA Gesellschaft für Abfallwirtschbvaft und Stadtreinigung mbH, Höherweg 100, D-40233 Düsseldorf, Germany
At the beginning of the $20^{\text {th }}$ century, the German and Swiss chemical industry supplied the whole world with brilliant and reproducible colours based on tar chemistry. Years later, toxic and environmentally hazardous properties of these compounds were discovered. Former areas of tar dyes production are classified as contaminated sites. With the breakthrough of chlorine chemistry, other new chemicals with very interesting properties became commercially successful on a global scale. Again, the detection of hazardous properties and experience with ecotoxicological effects lead to restrictions for the use of important organochlorine substances.

\section{实}

(c) 2012 Friege; licensee Springer. This is an Open Access article distributed under the terms of the Creative Commons Attribution License (http://creativecommons.org/licenses/by/2.0), which permits unrestricted use, distribution, and reproduction in any medium, provided the original work is properly cited. 
Two fundamental developments have to be mentioned:

- The enormous increase of mass flows of chemicals on a global scale.

- The global division of labour.

Both developments lead to the more or less global availability also of hazardous chemicals for the production and as ingredients in certain goods and in waste.

In the time lag between the placing of a chemical on the market and regulations after scientific findings about potential hazardous properties, the chemical is spread out in numerous application areas becoming part of the waste after use. How is waste management dealing with hazardous compounds brought into the technosphere? Which are the prepositions for a successful "recall" of a substance of concern? These questions cannot be answered by experiments, but only by the experience collected in case studies. In the following, two prominent groups of substances will be used as examples to answer these questions.

\section{Waste management as part of substance chain management}

Most commercial products are manufactured using a lot of materials from different origins. Production of goods in a global division of labour is a highly sophisticated management problem. Waste management is mostly solved on a local or regional level. The management of material chains comprises the steps of production, consumption and disposal including reuse, recycling and recovery if possible. Therefore, waste management is only a subsystem in the whole management of material chains $[2,3]$. What does that mean in daily life? We have to observe some important dilemmas $[4,5]$ :

- A time lag between the placing of the product on the market and the restrictions for use as well as a time lag between the start of production and the disposal of the last products in use.

- The dilution of the hazardous substance as component of products to a greater or lesser extent

- The high dissipation of products with the substance in question in the technosphere.

- The costs for proper disposal of products contaminated by a hazardous component; this is an incentive for mixing it up with normal waste.

\section{Case study PCBs}

\section{Chemical and physical properties}

Polychlorinated biphenyls (PCBs) are a group of 209 congeners which have been synthesized as technical mixtures (oils, waxes) characterized by their chlorine content (weight\%). The general formula is given in Figure 1. The melting points of the technical mixtures are considerably lower than the melting points of isolated congeners. To reduce the viscosity of the higher chlorinated mixtures, often trichlorobenzenes were added. PCBs are very persistent substances, especially higher chlorinated congeners. PCBs tend to accumulate in soil, sediments, and biota, the highest concentrations found in fat of marine predators and human beings. The intake of food, especially animal fat and fish, is the most important contamination pathway for humans.

At a first glance, PCBs seem to be a group of simply structured chemicals. Considering the physical properties, many characteristic features like melting points, partition coefficients and accumulation factors vary depending on the molecular weight and / or the chlorine content. But some properties change considerably with structure - congeners with the same total formula might be very different in toxicity and / or persistence. Some important physicochemical properties are presented in Figure 2:

- The partition coefficients of the congeners differ considerably thus leading to different speed of propagation in the environment.

- The melting and boiling points as well as the $\mathrm{K}_{\mathrm{ow}}$ increase with increasing substitution of hydrogen by chloride.

- The toxicity of those PCB congeners which have planar structures thus resembling to polychlorinated dibenzodioxins and dibenzofurans is far higher than the toxicity of non-planar PCBs. Therefore, threshold values for food are different for dl-PCBs and ndl-PCBs ("dioxin-like", "not dioxin-like").

Planar structures of PCBs are possible for congeners which have no $\mathrm{Cl}$ substitutions in the ortho position to the $\mathrm{C}-\mathrm{C}$ bond between the aromatic rings.

- The stability of congeners with the same chlorine content varies depending on the substitution patterns: If there are no directly neighboured $\mathrm{C}-\mathrm{H}$ bonds in a PCB molecule, the stability is quite

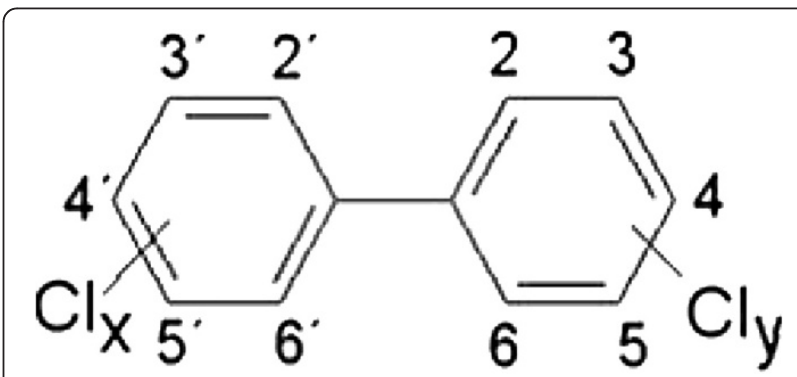

Figure 1 Structure of polychlorinated biphenyls (PCBs). 


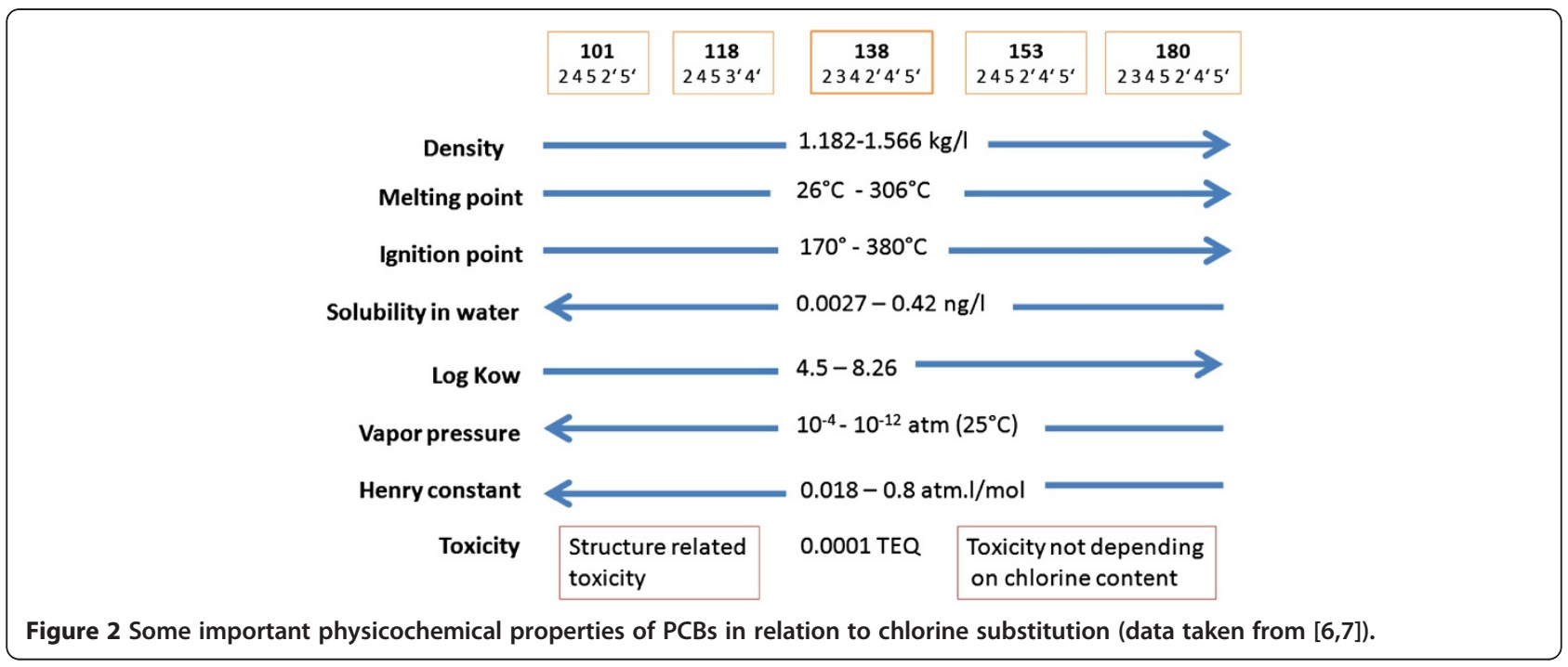

higher because the oxidation of carbon atoms in ortho position is not possible.

\section{Areas of application and waste management}

The production of PCBs started in 1930 driven by the need for hardly inflammable isolation material for capacitors and transformers. The most important areas of use are presented in Table 1 together with an assessment of the problems coming up with the separation of used products containing PCBs. Many production lines ceased already until the end of the 70ies due to several national PCB bans (Japan), but some producers were busy until the end of the 80ies to meet the demand for special applications or due to delayed legislation. The overall production is estimated at $1.5 \mathrm{Mio} \mathrm{Mg}$. In Europe, PCBs were banned first for "open" [8], then for "closed" applications [9]. But many of the closed applications turned out to be open in reality, as has been demonstrated for hydraulic fluids used in German coal mines, where up to two thirds of the annual consumption of PCBs were lost [10].

Even today, PCBs used for construction are a major source for contamination. About one third of the overall production of technical PCBs was applied for dyes and joint sealers as additives used in millions of buildings worldwide. Normally, details of the construction besides buildings statics are not documented for a long time. Therefore, present owners or inhabitants of older buildings do not know if PCBs have been used in certain materials. Only in the case of secondary contamination of ambient air or food detected by chance or by systematic search, those buildings were decontaminated. There

Table 1 Former use of PCBs and disposal

\begin{tabular}{|c|c|c|c|c|}
\hline & $\begin{array}{l}\text { Type of PCB } \\
\text { used }\end{array}$ & $\begin{array}{l}\text { Type of } \\
\text { Application }\end{array}$ & $\begin{array}{l}\text { Intended way / normal way } \\
\text { of disposal }\end{array}$ & Separation from other items \\
\hline Isolating agent in transformers & $\mathrm{Cl}>=54 \%$ & "closed" & Special waste & Easy \\
\hline $\begin{array}{l}\text { Isolating agent in large } \\
\text { capacitors }\end{array}$ & $\mathrm{Cl}<=42 \%$ & "closed" & Special waste & Easy \\
\hline $\begin{array}{l}\text { Hydraulic fluid in mining } \\
\text { equipment }\end{array}$ & Tri- and Tetra-CBs & "closed" & $\begin{array}{l}\text { Special waste / waste water from } \\
\text { mine draining }\end{array}$ & Difficult in underground mines \\
\hline $\begin{array}{l}\text { Heat transfer oil in industrial } \\
\text { applications }\end{array}$ & $\begin{array}{l}\text { Low chlorinated } \\
\text { mixtures }\end{array}$ & "closed" & Special waste & Easy \\
\hline $\begin{array}{l}\text { Isolating agent in small } \\
\text { capacitors }\end{array}$ & $\mathrm{Cl}<=42 \%$ & "closed" & $\begin{array}{l}\text { Waste from electric and electronic } \\
\text { equipment / household waste }\end{array}$ & $\begin{array}{l}\text { Possible in state of the art } \\
\text { sorting plants }\end{array}$ \\
\hline Additive to joint sealer & $\begin{array}{l}\text { All technical } \\
\text { mixtures }\end{array}$ & "open" & $\begin{array}{l}\text { Hazardous waste / mixed } \\
\text { construction waste }\end{array}$ & $\begin{array}{l}\text { Possible in state of the art } \\
\text { dismantling processes }\end{array}$ \\
\hline Additive to dyes & $\begin{array}{l}\text { All technical } \\
\text { mixtures }\end{array}$ & "open" & $\begin{array}{l}\text { Hazardous waste / mixed } \\
\text { construction waste }\end{array}$ & Nearly impossible \\
\hline Additive to textiles & $\begin{array}{l}\text { Low chlorinated } \\
\text { mixtures }\end{array}$ & "open" & $\begin{array}{l}\text { Hazardous waste / } \\
\text { household waste }\end{array}$ & Nearly impossible \\
\hline Additive to PVC & $\begin{array}{l}\text { High chlorinated } \\
\text { mixtures }\end{array}$ & "open" & $\begin{array}{l}\text { Hazardous waste / } \\
\text { household waste }\end{array}$ & $\begin{array}{l}\text { Possible in state of the art } \\
\text { sorting plants }\end{array}$ \\
\hline
\end{tabular}


is an unknown number of contaminated areas and buildings left ${ }^{\mathrm{a}}$.

In contrary to the examples presented above, transformers, heat exchangers and capacitors are "closed systems", if they are not accidentally damaged. As long as machines filled with PCBs had safely closed loops, the use of PCBs was further permitted [9]. This is the case for large electric appliances, which had to be identified by a certain label (e.g. "Clophen", "Arochlor") [11] serving as an information for workers, management, and authorities. This European directive covers all appliances with a volume of more than 51 liquid including PCBs at concentrations above $50 \mathrm{mg} / \mathrm{kg}$. To protect workers, limit concentrations for workplaces were defined mostly on a national level [12].

From the few examples presented, it is clear that a lot of difficult problems have to be solved mostly by proper waste management:

- Collection and destruction of contaminated building rubble coming from the clean-up of houses.

- Disposal of small capacitors filled with PCB from electric equipment, normally used in discharge lamps and electric household appliances.

- Collection and disposal of large capacitors used for industrial applications.

- Cleaning and sometimes refilling of large transformers.

- Collection and disposal of hydraulic oils completely or partially contaminated with PCBs.

- Collection and disposal of other goods (e.g. PVC parts containing PCB) from households and commerce.

- Reclamation of contaminated sites like former production plants, ruins from large building fires (e.g. department stores, administrative buildings with own electricity supply).

- Last, but not least: under thermal load, chlorine and organic substances react to form PCBs parallel to the "de novo" dioxin synthesis. This happens in particular on the surface of dust particles in the range between 200 and $400^{\circ} \mathrm{C}$. A correlation is found between the concentrations of dl-PCBs and PCDDs and PCDFs in the flue gas at the stack [13].

It is obvious that this mission could not be completed successfully. To avoid further contamination of the food chain, limit concentrations were introduced for food $[14,15]$, animal feed, soil, and sludge from waste water treatment [16].

As to the disposal, PCBs can be safely destroyed by incineration in rotary kilns or on the grate if temperatures above $900^{\circ} \mathrm{C}$ are maintained for some seconds. Legally, waste contaminated up to $50 \mathrm{mg} / \mathrm{kg}$ may be incinerated in MWI's. Rotary kilns which are typical for hazardous waste incineration are normally used for disposal of higher PCB concentrations. Former problems with the de novo synthesis of PCBs have been overcome by fast quenching of the flue gas to avoid the temperature window between 200 and $400^{\circ} \mathrm{C}$ and flue gas cleaning with activated coke. Thus, a modern incineration plant serves as a sink for PCBs and dioxins [17]. There are some other valuable techniques for the destruction of PCBs like the reaction with sodium or potassium, the hydrogenation, or plasma arc treatment. These techniques are fitted only for highly concentrated PCB waste. The disposal in former salt mines is a safe sink for transformers and condensers filled with PCB oils $[18,19]$.

Goods used by millions of people (dissipative use) are hardly collected separately, even if they can be identified by a special form or label. Therefore, nearly all small items containing PCBs have been disposed with household waste. Electric and electronic devices are collected separately since a couple of years to fulfil the WEEE directive. Capacitors containing PCBs and "electrolyte capacitors containing substances of concern" must be separated in sorting plants [20]. These capacitors with a unit weight between 100 and $300 \mathrm{~g}$ (a third of this being PCBs) [21] have been used until the end of the 70ies, may be also in the 80ies of the last century. From a technical point of view, more than $95 \%$ of all PCB in electronic waste can be separated by the first step in a sorting plant [22]. In a report of the German government, it is assumed that about $3.5 \mathrm{Mg}$ capacitors contaminated with PCBs were separated and disposed in 2008 by proper sorting [23]. But PCB contaminations have been found in sorting plants for e-scrap probably caused by accidentally destroyed capacitors [24,25].

Transformers and large capacitors filled with PCBs can be easily identified by the compulsory label. It is assumed that an overwhelming percentage of these items have been separately disposed. The use of appliances containing PCB with concentrations of more than $50 \mathrm{mg} / \mathrm{kg}$ is prohibited since the year 2000; exemptions could be granted until 2010. Instead of disposal of the complete transformer, isolating fluids can be exchanged by other chemicals. The complete cleaning of the contaminated transformer is somewhat difficult and should be done very carefully to avoid increasing PCB concentrations after refilling with other liquids [26]. Due to increasing copper prices, a lot of transformers already disposed under ground have been brought back to treatment plants. If the contaminated fluids are completely removed in a cleaning process, this might be a good method to save resources. A German company specialized on this treatment was closed down in 2011 by the responsible authorities because of remarkable pollution of its workers and contamination of the facility 
[27]. It is likely that there are similar cases in other countries which have either not been uncovered or not documented.

If PCBs are mixed with used mineral oils, the diluted contaminants are spread over a large volume of products. If waste oils are refined for the use as marine diesel, PCBs and its by-products will be emitted by the ships. To avoid this critical pathway, waste oils are also subjected to the European directive 76/769 [8]. Because of the costs for proper disposal of waste contaminated with PCB (actually the price is about $600 € / \mathrm{Mg}$ for large bulks and about $2-3 € / \mathrm{kg}$ for small items ${ }^{\mathrm{b}}$ ), criminal trafficking should be taken into account: Diluting contaminated liquids with other used solvents, faking the waste disposal code, export of contaminated waste for disposal in inappropriate facilities. Actions like this have been severely punished. Transboundary transports of waste contaminated with PCBs are restricted by the Basel convention which established an international regulation for the trading of dangerous waste.

As to contaminated sites, a lot of experiences have been collected in the last thirty years considering the pathways of different congeners into the environment as well as the metabolism of PCBs. Due to their low water solubility, most congeners do not move from soil to groundwater with the exception of liquid phases together with solvents. If PCBs are spread due to building fires or other accidents, the contamination of workers or residents nearby with PCBs and by-products like dioxins and furans might become a severe problem.

\section{Development of $P C B$ concentrations in man and environment}

There is no information about the amount of PCBs still resting in buildings or in other application areas to be disposed in future. We can proceed from the assumption that by far the largest part of PCBs has been disposed or emitted. Following an assessment for Germany, the emissions from the residual appliances were about $221 \mathrm{~kg}$ in 2009, whereas nearly $1.7 \mathrm{Mg}$ were emitted in 1990 [28]. This figure does not cover uncontrolled emissions from waste management. After a "clean up"-phase of more than thirty years, the concentrations of PCBs in man and environment have decreased remarkably: As to marine environment, this has been demonstrated recently for gull eggs in German coastal areas covering the period since 1988 [29]. A lot of similar results are obtained by suitable samples documented in the environmental specimen bank. The burden of man is decreasing slowly as is demonstrated in Table 2 for blood of young people (students from four universities). On the basis of an enormous number of milk samples, Fürst [30] demonstrated a continuous decrease of PCB concentrations after a peak between 1985 and 1990 and a second increase of concentrations at the end of the 90ies. The concentrations of the persistent highly chlorinated congeners decrease slowly in comparison with lower chlorinated congeners. But the ingestion of PCBs by food in Germany, especially fish, milk, eggs, meat, and vegetables is still in the range of the tolerable weekly intake [31].

\section{Case study CFCs / HCFCs \\ Physical and chemical properties}

Freon is a common name (trade mark by Dupont) for chlorofluorocarbons (CFCs) the molecular structure mostly consisting of one or two carbon atoms. At room temperature, most of these are in gaseous, some in liquid state of matter. The boiling points increase with increasing chlorine content of the molecule. CFCs are non-flammable. All halocarbons of this type are fugitive and also very persistent with half-life periods in the atmosphere of $>>10 y e a r s$. Due to scission of the molecules caused by UV rays in the stratosphere, $\mathrm{Cl}^{\circ}$ radicals are produced which react with ozone (chain reaction) thus decreasing the ozone concentration considerably (ozone depleting substances - ODS). Some are also very powerful greenhouse gases with GWP factors up to 10,000 as compared to $\mathrm{CO}_{2}$. Hydrochlorofluorocarbons (HCFCs) have similar properties, but are less dangerous with respect to ozone depletion. These substances have no relevant toxic properties with respect to man or animal. Many HCFCs are also not-flammable. Some prominent members of this family are presented in Figure 3.

The reactions of CFCs in the stratosphere leading to an increase of UV rays became an issue in the public, probably because of the popular picture of the ozone hole above the South Pole. Increasing UV ray intensity means also a higher probability for skin cancer, but epidemiological data do not provide a correlation for Australian people [33]. The ozone depletion potential (ODP) and the greenhouse warming potential (GWP) and the global emissions of several important members of the Freon family may be taken from Table 3.

\section{Areas of application and waste management}

By expanding Freon chemicals, they cool down (Joule Thomson effect). Freon substances are therefore excellent cooling agents; in the mid of the $20^{\text {th }}$ century, they substituted toxic ammonia and inflammable methyl chloride as common refrigerants for freezers. Due to their good solubility for many organic compounds, Freon substances are used in chemical reactions under pressure, i.e. for extractions. The use of Freon gases as foaming agents for polystyrene or polyurethane improves the isolating properties of the polymer foams. Freon compounds have been banned in international conventions ("Montreal protocol" [36]) starting in 1987. The 
Table 2 Concentration of important PCB congeners in blood plasma of German students (ng $\mathrm{ml}^{-1}$ fresh weight); data from the German environmental specimen banking [32]

\begin{tabular}{lcccccc}
\hline Sample origin & \multicolumn{3}{c}{$\mathbf{1 9 9 7}$} & & \multicolumn{2}{c}{$\mathbf{2 0 1 0}$} \\
\cline { 2 - 6 } & PCB 138 & PCB 153 & PCB 180 & PCB 138 & PCB 153 & PCB 180 \\
\hline Münster & 0.91 & 0.55 & 0.43 & 0.19 & 0.21 & 0.16 \\
\hline Greifswald & 0.68 & 0.52 & 0.31 & 0.15 & 0.11 \\
\hline Halle & 0.74 & 0.44 & 0.30 & 0.15 & 0.17 & 0.11 \\
\hline Ulm & 0.62 & 0.45 & 0.34 & 0.15 & 0.17 \\
\hline
\end{tabular}

Montreal Protocol signed in 1987 has been amended several times to accelerate the phase-out of certain substances, to include additional compounds, or to change control mechanisms. It is the first international treaty to achieve universal ratification by all 196 UN members. The signatory countries are obliged to reduce the production of Freon substances stepwise in relation to former production volumes. The use of individual compounds is phased out within reasonable time frames. The countries have to report production, import, export and destruction volumes to the Secretariat of the Protocol. In Table 4 the most important use pattern of fluorinated hydrocarbons is presented. By contrast to PCBs, CFCs and especially HCFCs are further produced in some countries. The substitution process is continuously going on by phasing out CFCs partially replaced by HCFCs thus increasing the banks of powerful greenhouse gases. Therefore, the substitution of CFCs by substances with low ODP as well as low GWP is of outstanding importance.

The Montreal protocol and its follower conventions focus on a production ban with controlled exceptions (e.g. from security reasons or laboratory use) of chlorinated and fluorinated hydrocarbons in relation to their ODP. The parties to the protocol including the European Community are not directly obliged to collect Freon from used products, but the governments have "to take appropriate decisions, consistent with the objectives of the Basel Convention and of the Montreal Protocol, in order to facilitate early phase-out of the production and consumption of the controlled substances of the Montreal Protocol" [37]. Thus, the Montreal Protocol accepts CFC emissions from banks. To decrease emissions from leakages, the German government enacted a regulation for large cooling and air<smiles>FC(F)[C@H](F)Cl</smiles>

Figure 3 Trichlorofluoromethane (F11), Chlorodifluoromethane (F22), and 1,1,1,2-Tetrafluoroethane (R134a). condition systems to ensure regular maintenance by skilled personal [38].

Freon gases from refrigerators, freezers, air condition equipment, and heat pumps shall be recovered for destruction, recycling or reclamation [39]. The destruction of Freon is regulated to avoid improper disposal techniques: Rotary kiln is approved for all types of ODS, municipal waste incineration is approved only for foams, and some plasma arc methods are approved for ODS with the exception of foams [39]. With respect to the WEEE directive [20], used refrigerators, freezers, and other electric and electronic devices have to be collected separately. The producers are obliged to take back used items and to pay for recycling and disposal. German authorities [40] urge companies running e-waste recycling facilities to recover $90 \%$ of the Freon compounds from used devices including the isolation foam of freezers. To prevent improper recycling, the export of unusable devices in non-EU countries has been prohibited. In daily life, the success of these efforts is rather poor: The yearly minimum collection target within the EU is $4 \mathrm{~kg}$ per inhabitant $\left(4 \mathrm{~kg} \mathrm{inh}^{-1} \mathrm{yr}^{-1}\right)$ with respect to all waste from electric and electronic equipment. In 2008, about $6.95 \mathrm{~kg} \mathrm{inh}^{-1} \mathrm{yr}^{-1}$ have been collected in the European Union, whereas the overall amount of waste from electric and electronic devices was about $20.8 \mathrm{~kg} \mathrm{inh}^{-1} \mathrm{yr}^{-1}$. (The latter figure has been calculated using an empirical correlation published by Huisman [41].) According to European statistics, freezers and refrigerators are recorded in the category of large household appliances ("white goods"). Therefore, we have only few data concerning the recycling of used appliances containing

Table 3 ODP (in relation to F-11) and GWP (in relation to $\mathrm{CO}_{2}$ ) for some typical Freon compounds (data from [34], ODP/GWP of F-22 [35])

\begin{tabular}{llccr}
\hline & Formula & $\begin{array}{c}\text { Global emissions } \\
\text { in } \mathbf{2 0 0 8}\left[\mathbf{G g ~ y r} \mathbf{~}^{-1}\right]\end{array}$ & ODP & GWP \\
\hline $\mathrm{F}-11$ & $\mathrm{CCl}_{3} \mathrm{~F}$ & $52-91$ & 1.0 & 4,000 \\
\hline $\mathrm{F}-12$ & $\mathrm{CCl}_{2} \mathrm{~F}_{2}$ & $41-99$ & 1.0 & 8,500 \\
\hline $\mathrm{F}-22$ & $\mathrm{CHClF}_{2}$ & $\begin{array}{c}385-481 \\
\text { (sum of all HCFCs) }\end{array}$ & 0,05 & 1,700 \\
\hline $\mathrm{F}-23$ & $\mathrm{CHF}_{3}$ & 12 & 0 & 14,200 \\
\hline $\mathrm{F}-134 \mathrm{a}$ & $\mathrm{CF}_{3}-\mathrm{CH}_{2} \mathrm{~F}$ & $149 \pm 27$ & 0 & 1,370 \\
\hline
\end{tabular}


Table 4 Use pattern of CFCs, HCFCs and fluorinated hydrocarbons

\begin{tabular}{lll}
\hline Area of use & Type of chemical used & Application \\
\hline Cooling agent (freezers, refrigerators...) & F-11 $\rightarrow \mathrm{HCFCs} \rightarrow$ Pentane & Closed \\
\hline Propellant gases for aerosols & $\begin{array}{l}\mathrm{F}-11, \mathrm{~F}-12 \rightarrow \mathrm{F}-134 \mathrm{a} \text { and other fluorinated } \\
\text { hydrocarbons } \rightarrow \text { Propane/Butane } \rightarrow \text { pressurized air }\end{array}$ & Open \\
\hline $\begin{array}{l}\text { Foam blowing agent for polyurethane } \\
\text { and polystyrene }\end{array}$ & F-11, F-12 $\rightarrow$ F-22 $\rightarrow$ F-134a, F-152a & Open \\
\hline Air condition for automobiles & F-22 $\rightarrow$ F-134a $\rightarrow 2,3,3,3-$ Tetrafluoropropene $\rightarrow \mathrm{CO}_{2}$ & partially open \\
\hline
\end{tabular}

Freon compounds. Actually, most of the devices to be disposed contain either F-11/F-12 or the successor products, i.e. partially halogenated hydrocarbons like F-22 or fluorinated hydrocarbons. In new refrigerators, pentane is used as cooling agent. In the State of Nordrhein-Westfalen (17.8 Mio inhabitants), 550,000 to 600,000 refrigerators have to be disposed per year. Until 2014, more than $50 \%$ of these devices will be contaminated with CFCs because of the long lifetime of household refrigerators [42]. Due to compulsory Freon elimination before metal recovery, the costs for the recycling of freezers are normally higher than the earnings from scrap. Therefore, refrigerators which do not work any longer (broken) cannot be sold by their owners. This might be the reason for the relatively high amount of refrigerators collected in comparison with other household appliances reported from the Dutch waste collection [43]. A considerable percentage of refrigerators and freezers are severely damaged by informal collectors who cut out copper tubes and compressors. Statistical data about these emissions are normally not found in government reports. Following an assumption by a German NGO, about $45 \%$ of Freon compounds from household appliances are emitted [44]. The problems show primarily up with kerbside collection. In the city of Düsseldorf $(\sim 600,000$ inhabitants), about $70 \%$ of the freezers and refrigerators declared for e-waste collection are damaged or stolen [45]. But also appliances brought to recycling yards are sometimes damaged. In the recycling facilities, Freon compounds used in the compressor and in the isolation must be separated in a first step. The recovery target for these contaminants is $90 \%$ according to German authorities [40]. Following some random samples [46], the recovery targets are not met by most recycling facilities. The emissions from German point sources in 2009 add up to $0.82 \mathrm{Mg}$ CFCs and 21.9 Mg HCFCs, respectively (data taken from [47]). Assuming a mean amount of 250 g Freon in a refrigerator, 2.5 million items to be disposed per year of which $50 \%$ are filled with CFCs and $45 \%$ loss during collection, the overall emission from this source is about $140 \mathrm{Mg}$ per year. Thus, the diffuse sources mainly caused by improper waste management are far more important than the point sources.
There are no comparable regulations for construction and demolition waste, though the amount of CFCs used in polymer foams is also important.

Another interesting example is the case of R-134a (see Tables 3 and 4) which is used since the nineties in automotive air condition appliances as a substitute for F-22. Due to lack of tightness of these appliances, part of the cooling agent used is emitted. According to a German study based on reports of car repair shops the losses added up to $8.2 \%$ per year with respect to the year 2000 [48].

\section{Development of environmental concentrations of CFCs and HCFCs}

The amount of chemicals with high ODP produced worldwide has decreased following the Montreal protocol and further international treaties. Because of the high volatility of the substances in question, the real decontamination of the technosphere can only be demonstrated by measurements in the troposphere followed by model calculations for the development of the ozone concentration. As a result of the implementation of the conventions mentioned before, the concentration of chlorine and of fully halogenated CFCs is decreasing, whereas the amount of partially halogenated chemicals like HCFCs is increasing again. The influence of improper waste management on the overall development cannot be assessed quantitatively. But closing the sources of illegal emission of Freon compounds would help to revitalize the earth's ozone belt years earlier. The decontamination of the stratosphere will need a lot of time. Actually, the ozone layer is expected to return to its pre-1980 levels around the middle of the $21^{\text {st }}$ century [49].

\section{Discussion}

The ban of hazardous substances or severe restrictions for their use is the most important prerequisite for the decontamination of the environment. As has been also demonstrated in the examples above, the clean up phase is delayed.

- by the lifetime of products containing the contaminants in question, 
- by the amount of these chemicals emitted during their life cycle,

- by the persistence of the emitted substances in natural environment.

When the used products leave households, workshops, and industrial facilities, identification and separation from other waste is often very difficult. In the cases reported here, "open applications" of these substances being critical to man and/or environment were banned in a first step to avoid further emission into the environment (e.g. use in aerosols, paintings, foams, liners). In both cases reported here, the predominant part of contaminants was used in "closed applications". As may be taken from the use of PCBs in mining equipment and the use of R-134a in automotive air conditioning, many applications in so-called closed systems turned out to be open in reality. Therefore, the use of substances in closed systems has to be controlled carefully to avoid unwanted emissions.

In the case of PCBs, numerous regulations have been issued to avoid the mixture of waste containing PCBs with other waste. This worked from several reasons:

- As to equipment filled with PCBs for further use, the PCB content was indicated by a label (trade name "Clophen", "Arochlor"). In combination with the limit values established for workers' protection, the correct disposal of these items could be assured.

- If the limit of PCBs in used oils is exceeded, the owner is enforced to destruct the complete oil batch by incineration in rotary kilns. Acting against the law is severely punished. Therefore, mixing up of low contaminated oil with high contaminated oil does not pay and is looked at as a crime.

- Contamination of poultry after application of polluted fodder leads to destruction of food, if the limit values for food are exceeded. Farmers became therefore cautious with regard to their animal feed.

- Transboundary shipment of PCB waste is regulated by the Basel convention.

As demonstrated for e-scrap, PCBs can only partially be separated due to accidental damage of appliances and lack of information about the use of capacitors filled with PCBs in household equipment.

In the case of Freon compounds used in closed applications like compressors, the regulations for safe disposal do not work successfully mostly due to activities of the informal sector. In contrary to large appliances for commercial use (transformers,...), the enforcement of regulations for highly dissipated devices is very difficult. Therefore, the informal sector acts more or less uncontrolled by the responsible authorities ". As to "open" applications of Freon substances like propellant gases, only the residual content from spray cans is destructed using appropriate disposal techniques.

There is another interesting parallel experience collected with both groups of chemicals: Especially in the case of electric appliances, these chemicals contaminate precious metals, mostly copper. Recent local contaminations by improper recycling of transformers which had been safely disposed years before [27] have been propagated by the intrinsic value of metals in used devices like transformers. Increasing prices for metals on the market will therefore enhance unsafe waste management practices.

It is necessary to establish safe procedures for the disposal of contaminated waste. In both cases presented, these procedures have been developed. Besides some chemical destruction methods and plasma arcs rarely used, incineration $>900^{\circ} \mathrm{C}$ or $>1200^{\circ} \mathrm{C}$ with recovery of the halogens $(\mathrm{HCl}, \mathrm{HF}, \ldots)$ is state of the art.

\section{Conclusions}

When the "life cycle" of a product comes to its end, waste management is responsible for proper handling, recycling of valuables in the waste, and disposal of hazardous compounds in the product. Very often, a separation of valuable and hazardous compounds in those products is not possible. Substances banned for further use will show up in the waste chain even if the products are out of the market since a long time. The time tables for phasing out these substances are often very different depending on national legislation. Moreover, people in industrialized countries, especially skilled workers, are more aware of harmful substances in products as people in developing countries. Globalization of trade without harmonizing the rules for the use of hazardous substances may therefore end up with serious contamination of secondary raw materials by hazardous substances which have not been properly separated in the waste chain.

Hazardous compounds may be separated successfully from used products or waste,

- If they are mostly used in industry and not in households,

- if they can be identified as part of certain products,

- if their concentration in these products is rather high,

- if technical problems come up when they contaminate secondary raw materials,

- if there is international support for proper waste management.

If separation of hazardous materials and resources is not possible, state of the art incineration (WtE) is the 
approved method for the disposal of hazardous organic waste as well as of contaminated products.

Lack of information about potential contamination of used products may be one reason for unsafe procedures in waste management. It turned out that regulations for workers' protection against the substances in question facilitate the identification of contaminated areas and equipment. Therefore, capacity building and right to information for workers seems to be an important tool not only for the protection of man, but also for better waste management at the origin.

Material input for long-range application should be very carefully documented to facilitate safe deconstruction. The largest material streams result from pulling down of houses or infrastructure. Contamination of debris can be avoided if deconstruction based on detailed information about the construction materials is carried out. Therefore the introduction of "construction passports" would be very helpful for the documentation of materials used for construction and refurbishment. The construction passport would close the knowledge gap between the start and the end of the products' lifetime.

Activities of the informal sector may considerably disturb the "cleanup" of the technosphere by collection and recycling of products contaminated with hazardous substances. There is no unique recipe how to deal with those activities: disseminating knowledge among people in the informal sector might be one important step. But the responsible authorities should also enforce separate collection of hazardous used products and hazardous waste by skilled personal to avoid unsafe recycling procedures.

The new European "waste hierarchy" is a general management rule for the waste sector. From the results presented here, it is concluded that waste management of products should be supported by mass flow balances for hazardous chemicals as well as for scarce non-renewable resources. The equations "recovery is better than disposal" and "material recovery is better than energy recovery" may lead to problems for man and environment if used without further insight into the life cycle of the products in question.

The question arises, if problems like those presented here may show up again despite the progressive chemical policy. Due to the principles followed by REACH, the responsibility of the producers and importers for the safe use of their products has been enhanced. Manufacturers introducing a new application field for an already registered compound are obliged to re-register. The experiments to be executed before registering and marketing of new chemicals should minimize the risk of severe misjudgements about the hazards also in case of special appliances. But errors cannot be excluded. As to the prominent case of nano materials, the registration is under discussion, because they might behave in another way than the molecules in macroscopic structure.

\section{Endnotes}

${ }^{a}$ To give an example: PCB contamination of a building at a German University was reported in 2012: "Verunsicherung an der Uni: Wie gefährlich ist PCB?", WZ Düsseldorf, 15.2.2012.

${ }^{\mathrm{b}}$ Prices announced by idr-eg, hazardous waste management company, Germany, March 2012.

${ }^{\mathrm{c}}$ From the author's experience, many authorities do not officially report these problems, because they are not in a position or not willing to prosecute environmental crimes by the informal sector.

\section{Competing interests}

The author declares that he has no competing interests.

Received: 1 July 2012 Accepted: 3 September 2012

Published: 21 November 2012

\section{References}

1. Henseling KO, Salinger A: Teerfarben - Keimzelle der modernen Chemieindustrie. In Das blaue Wunder. Zur Geschichte der synthetischen Farben. Edited by Andersen A, Spelsberg G. Köln: Kölner Volksblatt Verlag; 1990.

2. Brunner $\mathrm{PH}$, Rechberger $\mathrm{H}$ : Practical Handbook of Material Flow Analysis: Boca Raton; 2004. ISBN 1-5667-0604-1.

3. Friege $H$ : Von der Abfallwirtschaft zum Management von Stoffströmen. Müll und Abfall 1997, 29(1):4-13.

4. Friege $\mathrm{H}$ : Ressourcenschonung am Beispiel der Elektro- und Elektronikaltgeräte I. Grenzen des WEEE-Ansatzes. Müll und Abfall 2012, 44(2):80-93.

5. Friege $\mathrm{H}$ : Ressourcenschonung am Beispiel der Elektro- und Elektronikaltgeräte II. Ansätze für einen effizienteren Umgang mit nicht erneuerbaren Ressourcen. Müll und Abfall 2012, 44(6):307-317.

6. Fiedler H: Polychlorinated Biphenyls (PCBs): Uses and Environmental Releases: UNEP; 1997. http://www.chem.unep.ch/pops/pops_inc/proceedings/ bangkok/fiedler1.html, accessed 12.2.2012.

7. Li N, Wania F, Lei YD, Daly GL: A Comprehensive and Critical Compilation, Evaluation, and Selection of Physical-Chemical Properties Data for Selected PCB. J Phys Chem Ref Data 2003, 32(4):1545-1590.

8. EC: Council Directive 76/769/EEC of 27 July 1976 on the approximation of the laws, regulations and administrative provisions of the Member States relating to restrictions on the marketing and use of certain dangerous substances and preparations. OJ L 1976, 262:201-203.

9. EC: Council Directive 85/467/EEC of 1 October 1985 amending for the sixth time (PCBs/PCTs) Directive 76/769/EEC on the approximation of the laws, regulations and administrative provisions of the Member States relating to restrictions on the marketing and use of certain dangerous substances and preparations. OJ $L$ 1985, 269:56-58.

10. Rauhut $A$, quoted after Friege $H$, Nagel R: Umweltgift $P C B$. Freiburg: BUND-Information 21; 1982.

11. EC: Council Directive $96 / 59 / E C$ of 16 September 1996 on the disposal of polychlorinated biphenyls and polychlorinated terphenyls ( $P C B / P C T)$. OJ L 1996, 243:31-35.

12. Technische Regeln für Gefahrstoffe. Arbeitsplatzgrenzwerte (TRGS 900). http://www.baua.de/de/Themen-von-A-Z/Gefahrstoffe/TRGS/pdf/TRGS-900. pdf?_blob=publicationFile\& $\mathrm{v}=8$.

13. Johnke B, Menke D, Börske J: Neue Bewertung bei den Toxizitätsäquivalenten für Dioxine/Furane und für PCB durch die WHO. UWSF - Z. Umweltchem. Ökotox 2001, 13(3):175-180.

14. EC: Commission Regulation (EC) No 1881/2006 of 19 December 2006 setting maximum levels for certain contaminants in foodstuffs. OJ L 2006, 364:5-24.

15. EC: Commission Regulation (EC) No 565/2008 of 18 June 2008 amending Regulation (EC) No 1881/2006 setting maximum levels for certain 
contaminants in foodstuffs as regards the establishment of a maximum level for dioxins and PCBs in fish liver. OJ L 2008, 160:20-21.

16. Klärschlammverordnung, zuletzt geändert am 9.11.2010. http://www. gesetze-im-internet.de/bundesrecht/abfkl_rv_1992/gesamt.pdf.

17. Bilitewski B, Härdtle G, Marek K: Abfallwirtschaft: Handbuch für Praxis und Lehre. 3rd edition. Berlin; 2000:254-255. ISBN 3-540-64276-5.

18. Länderarbeitsgemeinschaft Abfall: LAGA-Merkblatt 24: Entsorgung von PCB-haltigen Reststoffen und Abfällen. In Müll Handbuch. Edited by Bilitewski B, Schnurer H, Zeschmar-Lahl B; 1992. Kz. A8375.

19. Umweltbundesamt: $P C B$-haltige Geräte in Deutschland. http://www umweltbundesamt.de/abfallwirtschaft/sonderabfall/pcb.htm, accessed 7.1.2012.

20. EC: Directive 2002/96/EC of the European Parliament and of the Council of 27 January 2003 on waste electrical and electronic equipment (WEEE). OJ L 2003, 37:24

21. European Environmental Agency: Waste from electric and electronic equipment - quantities, dangerous substances and treatment methods. http://eea.eionet.europa.eu/Public/irc/eionet-circle/etc_waste/library?!=/ working_papers/weeepdf/_EN_1.0_\&a=d accessed 12.11.2010.

22. Cuhls C: Stoffstrombilanzierung bei der Aufbereitung von Altfahrzeugen und Elektronikschrott in Shredderanlagen. In Abfallvermeidung und verwertung, Deponietechnik und Altlastensanierung. Edited by Hengerer D, Hofer M, Lorber KE, Ragoßnig A, Nelles M: Balkema; 2000:189-194. ISBN 9058091813.

23. Deutsche Bundesregierung: Bericht der Bundesregierung zu den abfallwirtschaftlichen Auswirkungen der $\S \S 9-13$ des ElektroG. Berlin: Deutscher Bundestag, BT-Drs; 2011 17/4517.

24. Bezirksregierung Arnsberg. http://www.bezreg-arnsberg.nrw.de/presse/2010/ 12/204_10/index.php, accessed 7.1.2012.

25. Bezirksregierung Münster. http://www.bezreg-muenster.nrw.de/startseite/ presse/pressearchiv/2011/20110216_Bezirksregierung_Muenster_legt_AGR_ Zwischenlager_Gelsenkirchen_wegen_PCB_Belastung_still/index.html, accessed 7.1.2012.

26. Bonk L, Böckler M, Göller F, Jasny W, Tigges E: Einsatz, Entsorgung und Recycling PCB-haltiger Bauteile und Komponenten der Elektrotechnik. Gefahrstoffe - Reinhaltung der Luft 2011, 71(1/2):15-19.

27. Landesamt für Natur- und Umweltschutz NRW: Ereignisse und Störfälle in Industrieanlagen. http://www.lanuv.nrw.de/umwelt/schadensfaelle/anlagen. $\mathrm{htm}$, accessed 19.5.2012.

28. Umweltbundesamt: Emissionen persistenter organischer Schadstoffe. http:// www.umweltbundesamt-daten-zur-umwelt.de/umweltdaten/public/theme. do?nodeldent=2361, accessed 4.3.2012.

29. Fliedner A, Rüdel H, Jürling H, Müller J, Neugebauer F, Schröder-Kermani C: Levels and trends of industrial chemicals (PCBs, PFCs, PBDEs) in archived herring gull eggs from German coastal regions. Environ Sci Eur 2012, 24:7. doi:10.1186/2190-4715-24-7.

30. Fürst $P$ : Dioxins, $P C B$, and other organohalogen compounds in human milk. Mol Nutr Food Res 2006, 50:922-933.

31. Bundesinstitut für Risikobewertung: Aufnahme von Umweltkontaminanten über Lebensmittel. Berlin; 2010. ISBN 3-938163-70-4.

32. http://www.umweltprobenbank.de/de/documents/investigations/results/ analytes?analytes $=10011$ \&sampling_areas $=10102 \&$ sampling years $=1982.2010 \&$ specimen types $=10004$, accessed 21.11.2010.

33. Moan J, Dahlback A: The relationship between skin cancers, solar radiation, and ozone depletion. Br J Cancer 1992, 65(6):916-921.

34. World Meteorological Organisation: Scientific Assessment of Ozone Depletion: 2010. Geneva: Global Ozone Research and Monitoring Project, Report No. 52; 2011.

35. http://www.engineeringtoolbox.com/refri.

36. UNEP: The Montreal Protocol on Substances that Deplete the Ozone Layer. Nairobi; 2000. ISBN: 92-807-1888-6.

37. UNEP: Decision V/24; http://ozone.unep.org/Publications/MP_Handbook/MPHandbook-2009.pdf, accessed 13.2.2012.

38. Verordnung zum Schutz des Klimas vor Veränderungen durch den Eintrag bestimmter fluorierter Treibhausgase (ChemikalienKlimaschutzverordnung). 2008, BGBI. I, 1139-1144, 7.7.2008.

39. EC: Regulation No 1005/2009 of the European Parliament and of the Council of 16 September 2009 on substances that deplete the ozone layer. OJ L 2009, 286(1-30):2009.
40. Länderarbeitsgemeinschaft Abfall: Anforderungen zur Entsorgung von Elektronik-Altgeräten. LAGA-Mitteilung 31. www.laga-online.de accessed 26.8.2010.

41. Huisman J: WEEE recast: from $4 \mathrm{~kg}$ to $65 \%$ : the compliance consequences. Bonn: United Nations University; 2010.

42. Landesamt für Natur-, Umwelt- und Verbraucherschutz NW: Entsorgung FCKW-haltiger Haushaltskühlgeräte in Nordrhein-Westfalen. Recklinghausen: LANUV-Fachbericht 21.

43. Complementaire e-waste stromen in Nederland versie 2.0. http://www.wecycle. nl/uploads/pdf/onderzoek/2010/2008-07\%20complementaire\%20stromen\% 20rapport\%20v.2\%20 W+B.pdf, accessed 28.7.2011.

44. Deutsche Umwelthilfe: Falsche Entsorgung von Kühlschränken setzt FCKW frei. http://www.konsumo.de/news/1919-Umwelt-Falsche-Entsorgung-vonKuehlschraenken-setzt-FCKW-frei, accessed 15.3.2009.

45. Friege $\mathrm{H}$, Schmidt $\mathrm{O}$, Hinken G: Sammlung und Gewinnung von Wertstoffen aus Abfällen - Chancen und Hindernisse. In Abfall-RecyclingAltlasten, Volume 34. Edited by Pinnekamp J. Aachen; 2008. 10/1-10/19.

46. Boeckh M: Kühlmittel erhitzen die Gemüter. Entsorga-Magazin 2011, 7:10-14.

47. E-PRTR: http://prtr.ec.europa.eu/, accessed 17.3.2012.

48. Schwarz R: Emissionen des Kältemittels R134a aus mobilen Klimaanlagen. Frankfurt: Studie im Auftrag des Umweltbundesamts 36009 006, Öko-Recherche Büro für Umweltforschung und -beratung; 2001.

49. http://www.unep.fr/ozonaction/information/mmcfiles/7508-eOASI2011_TippingtheBalance.pdf, accessed 21.1.2012.

doi:10.1186/2190-4715-24-35

Cite this article as: Friege: The role of waste management in the control of hazardous substances: lessons learned. Environmental Sciences Europe 2012 24:35.

\section{Submit your manuscript to a SpringerOpen ${ }^{\circ}$ journal and benefit from:}

- Convenient online submission

- Rigorous peer review

- Immediate publication on acceptance

- Open access: articles freely available online

- High visibility within the field

- Retaining the copyright to your article

Submit your next manuscript at $>$ springeropen.com 